\title{
Climate variability over the reef corridor of the southwestern Gulf of Mexico
}

\author{
José de Jesús SALAS-PÉREZ ${ }^{1 *}$, Adán Guillermo JORDÁN-GARZA ${ }^{1}$ and David SALAS-MONREAL ${ }^{2}$ \\ ${ }^{1}$ Facultad de Ciencias Biológicas y Agropecuarias, Universidad Veracruzana, Tuxpan,Veracruz, México. \\ ${ }^{2}$ Instituto de Ciencias Marinas y Pesquerías, Universidad Veracruzana, Boca del Río, Veracruz, México. \\ *Corresponding author; email: jsalasp39@yahoo.es
}

Received: June 17, 2019; accepted: February 18, 2020

\begin{abstract}
RESUMEN
Las tendencias climáticas locales y regionales impulsarán las tasas de cambio en los ecosistemas costeros. Se caracterizaron series temporales de 35 años de duración de la temperatura del aire, la humedad relativa y la precipitación en el sistema arrecifal del suroeste del Golfo de México. Los datos provinieron de un modelo climatológico, pero para evaluar su fluctuación local, las diferencias con los registros in situ se estimaron cuando los registros estuvieron disponibles. Las tres variables mostraron coherencia con el registro de alta presión del sistema de alta presión del Atlántico norte en tiempos similares y en periodos de 4 a 8 y $>10$ años, lo que evidencia la influencia, a escala regional, de las señales de El Niño Oscilación del Sur (ENOS) y la Oscilación Multidecadal del Atlántico (AMO). Las anomalías positivas y negativas mostraron tendencias lineales que representan un aumento de eventos más cálidos y húmedos dentro de una climatología estacional en el área de estudio del Golfo de México, y presentaron una correlación relativamente alta $(>0.5)$ con el modo AMO. Los periodos de retorno de valores extremos variaron de 5 a 10 años. En general, las tendencias y los eventos extremos mostraron patrones similares a escala regional, pero el aumento de la lluvia puede ser mayor en la ubicación central del área de estudio. Una mayor frecuencia de eventos extremos podría amenazar los ecosistemas locales y a la población. Son necesarios planes y acciones de gobierno a escala local para lograr una adaptación preventiva al clima.
\end{abstract}

\begin{abstract}
Local and regional climate trends drive rates of change in coastal ecosystems. To better understand local climate, 35-year-long time series of air temperature, relative humidity and rainfall were analyzed along the reef corridor of the southwestern Gulf of Mexico. Data came from a climatological model and to assess its local performance, differences with in situ records were estimated when available. All three variables showed coherence with the record of the North Atlantic high-pressure system (also known as the Bermuda High) at similar times and periods between 4 to 8 and $>10$ years, evidencing the influence, at this regional scale, of El Niño Southern Oscillation (ENSO) and the Atlantic Multidecadal Oscillation (AMO). Positive and negative anomalies showed linear trends depicting an increase of warmer and moister events during a seasonal climatology at the reef corridor of the southwestern Gulf of Mexico and a relatively higher correlation (>0.5) with the AMO mode. Return periods of extreme values varied between 5 and 10 years. In general, trends and extreme events showed similar patterns at a regional scale, but the increase in rainfall is expected to be larger near the central location of the study area. A higher frequency of extreme events could threaten local ecosystems and human populations; therefore, plans and actions at local scales of governance are needed to achieve preemptive climate adaptation.
\end{abstract}

Keywords: Sistema Arrecifal Veracruzano National Park, Los Tuxtlas reefs, long-term linear trends, extreme values, ENSO signal, AMO signal. 


\section{Introduction}

The North Atlantic Subtropical High (NASH) system has intensified over the last 40 years, associated with anthropogenic warming, extending its western ridge further west (Li et al., 2011; Díaz-Esteban and Raga, 2018). The NAHS has a direct effect over the regional coastal climate, as shown by Zhu and Liang (2013) over the eastern United States. To characterize the NASH variability, Zhu and Liang (2013) used an index that is the result of a sea-level pressure gradient between two specific locations: Bermuda $\left(40^{\circ} \mathrm{N}, 60^{\circ}\right.$ $\mathrm{W})$ and New Orleans $\left(30^{\circ} \mathrm{N}, 90^{\circ} \mathrm{W}\right)$. Previous studies computed a similar index using the location of New Orleans but different locations near Bermuda, such as $\left(32.5^{\circ} \mathrm{N}, 65^{\circ} \mathrm{W}\right)$ by Katz et al. (2003) and $\left(35^{\circ}\right.$ $\mathrm{N}, 65^{\circ} \mathrm{W}$ ) by Ortegren et al. (2011). Those studies indicate that positive values of the Bermuda Index corresponded to the westward displacement of the western edge of the NASH from its normal position (Katz et al., 2003).

A coral reef corridor lies close to the shore along the southwestern Gulf of Mexico, with coastal lagoons, mangroves, and towns in the state of Veracruz, Mexico. Human activities along this coastline depend on fishing, tourism, oil, gas and commercial pier activities (Jordán-Dahlgren and Rodríguez-Martínez, 2003; Tunnell et al., 2007; Jiménez-Badillo, 2007; Mendoza-Cantú et al., 2011). Yet, ecosystems' functions are threatened, among other forcing factors, by the effects of climate change driving extreme climatic events (Moberg and Folke, 1999; Hoegh-Guldberg et al., 2007), threatening also the lives of over seven million people along the coastline (INEGI, 2010). A good understanding of local scale present climate variability is crucial to understand and predict future scenarios and to design adaptation strategies (Adger et al., 2005; Tang et al., 2010; Pandolfi et al., 2011; Palumbi et al., 2014). The climate of the reef corridor of the southwestern Gulf of Mexico could be influenced by the westward displacement of the NASH. This regional climate variability could influence changes in coastal ecosystems, from coral bleaching events and coral-disease epizootics, to even life-threatening extreme weather events. Thus, one hypothesis of this study is that regional climate fluctuations on the reef corridor of the southwestern Gulf of Mexico are potentially driven by the NASH displacement further west than its normal position (Fig. 1).
Atmospheric and oceanic teleconnections from the tropics and extra-tropics may also modulate climate variability in the Gulf of Mexico on a broader range of time and spatial scales (Kucharski et al., 2010). Teleconnections of the El Niño Southern Oscillation (ENSO) and the North Atlantic Oscillation (NAO) could influence climate variability in the Gulf of Mexico associated with the location and strength of the NASH. Such oscillations could influence regional air temperature and precipitation in areas of the basin particularly sensitive to floods/droughts (Saravanan and Chang, 2000; Stahle and Cleaveland, 1992; Salas-Pérez and González-Gándara, 2016).

Tett et al. (2002) strongly suggest that anthropogenic forcing (by tropospheric ozone, well-mixed greenhouse gases alone, sulfate aerosol) over the worldwide climate have been the dominant cause of air temperature changes over 30-50 years around the world, following a periodicity related to the Multidecadal Atlantic Oscillation (AMO). However, natural forcing like solar irradiance and stratospheric aerosol due to explosive volcanic eruptions could influence climate variability in smaller proportions. Thus at large scale, climate variability response to anthropogenic and natural forcing could cause temperature changes at regional and local scales too. In conjunction, these signals could potentially affect climate anomalies and trends on the three main areas of the Veracruz-reef systems of the reef corridor of the southwestern Gulf of Mexico: Sistema Arrecifal Lobos-Tuxpan (SALT, Spanish acronym), Parque Nacional Sistema Arrecifal Veracruzano (PNSAV) and Los Tuxtlas reefs (Jordán-Garza et al., 2017; Salas-Pérez and Jordán-Garza, 2018). Because it is unclear how local climate will follow global climate trends, this study analyzed trends of key selected climate variables from two meteorological stations next to the three main Veracruz-reef systems: Tuxpan, Veracruz and Coatzacoalcos, using the National Center for Environmental Predictions and North American Regional Reanalysis (NCEP-NARR) model (Mesinger et al., 2006). The objectives of the study were to (1) identify common oscillations of local climate variables and the North Atlantic High-pressure System (NASH); (2) characterize local trends of climate anomalies at three locations (north, central, south) along the coastal Veracruz; and (3) identify return periods of climatic anomalies. 

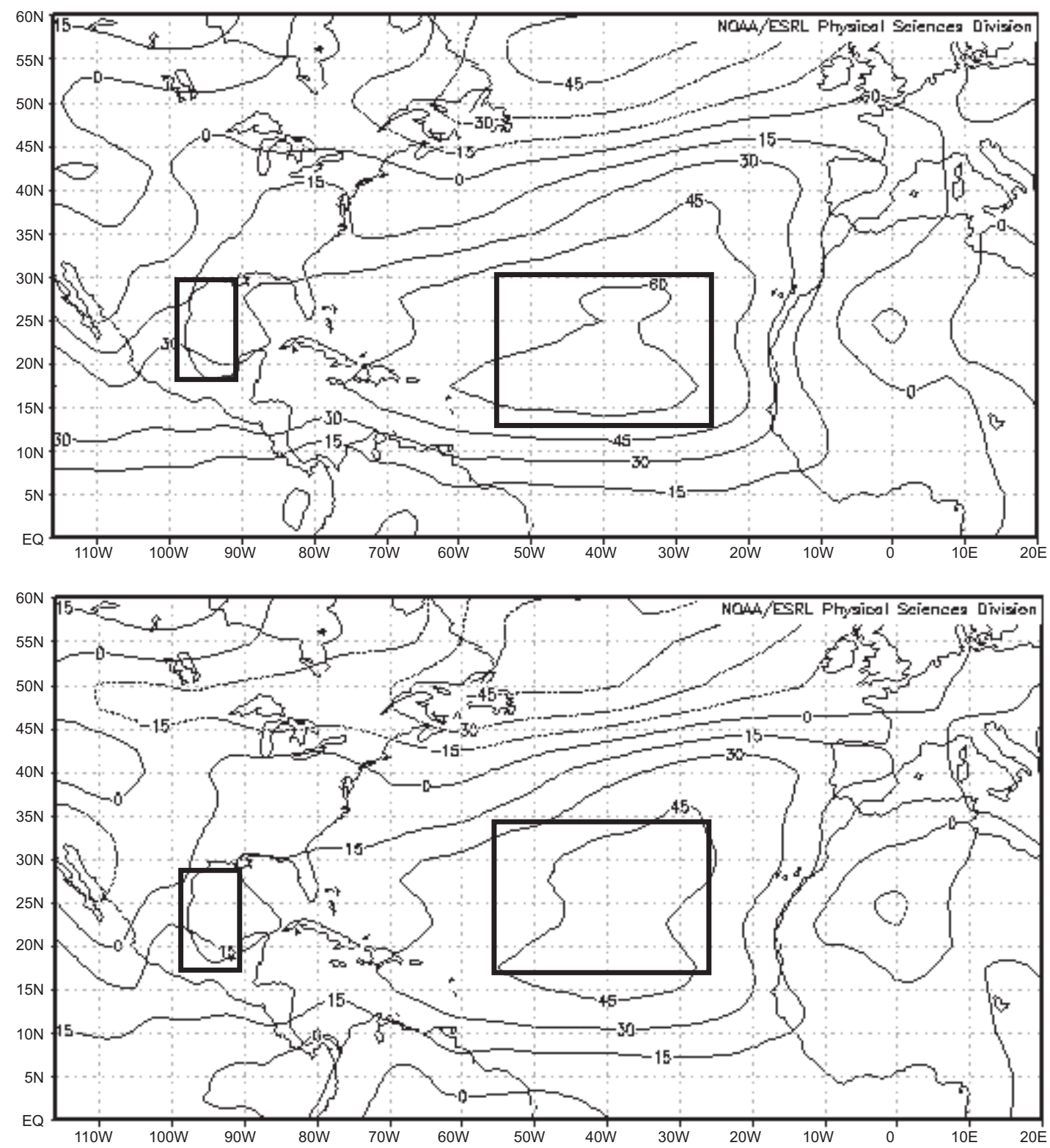

Fig. 1. Anomalous mean sea-level-pressure field derived from daily maps for a 66-year period. Upper panel: 1948 to 1979; lower panel: 1980 to 2015. Note the displacement of the NASH between these two periods over the Atlantic Ocean (black squares) and Gulf of Mexico, and the consequent displacement around the Veracruz coast (black rectangles). Image provided by the Physical Sciences Division, ESRL/ NOAA, from their website at http://www.esrl.noaa.gov/psd/

\section{Materials and methods}

\subsection{Study region and data sets}

The reef corridor is in the central part of the southwestern Gulf of Mexico (Fig. 2). Numerous rivers, wetlands and lagoons characterize the coastal area (Carricart-Ganivet and Merino, 2001; Rivera-Guzmán et al., 2014; Salas-Pérez and González-Gánda- ra, 2016; Salas-Pérez and Jordán-Garza, 2018). Despite conditions driven by river discharges that cause high variability in turbidity, temperature, salinity, etc. (Salas-Pérez et al., 2008; Jordán-Garza et al., 2017), numerous reefs have developed and are distributed in the abovementioned three main systems (Fig. 2). 
Daily time series for air temperature, relative humidity and atmospheric pressure at mean sea level dating from 1980 to 2015 were provided by the Servicio Meteorologico Nacional (National Weather Service) and the Comisión Nacional del Agua (National Water Commission). These data came from the Tuxpan (north) and Veracruz (central) meteorological stations (Fig. 2). The data sets were inspected for outliers (values larger than three standard deviations from the mean) and missing daily values were replaced using linear interpolation (Salas-Pérez et al., 2007, 2012). No station data were available neither for Coatzacoalcos nor for rainfall at any location. Thus, NCEP-NARR modeled data were downloaded from their site at http://www.esrl.noaa.gov/psd/data. To select the data, three reanalysis grid points were selected around the study zones (Fig 2). The distance between the reanalysis grid points to the meteorological stations was 8 and $4 \mathrm{~km}$ for Tuxpan and 1 and 4 $\mathrm{km}$ for Veracruz (Fig. 2).

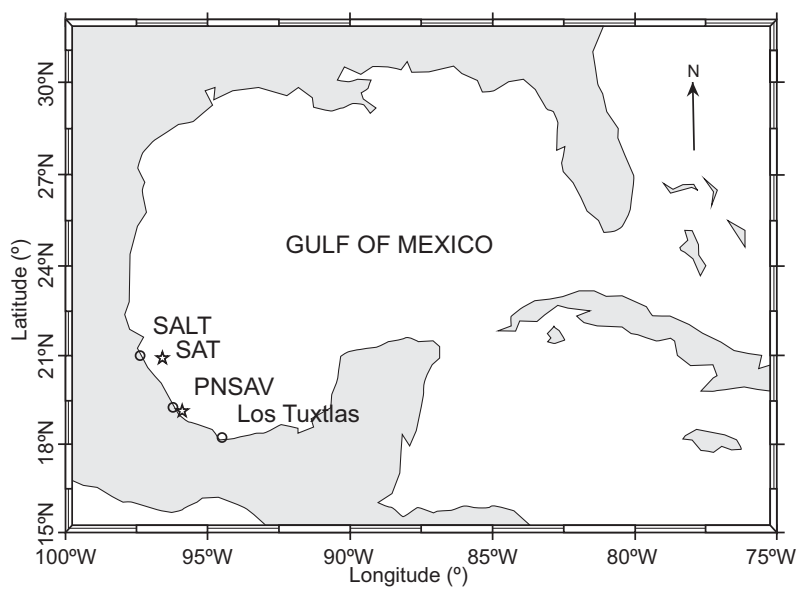

Fig. 2. Reef corridor of the southwestern Gulf of Mexico showing the three main reef systems: Tuxpan (SALT), Veracruz (PNSAV) and Coatzacoalcos (Los Tuxtlas). The meteorological stations and the NCEP-NARR model grids are shown with pentagrams and circles, respectively.

Also, a matching daily time series (1980-2015) of the atmospheric pressure at mean sea level of the $\mathrm{NASH}\left(32^{\circ} \mathrm{N}\right.$ and $\left.66^{\circ} \mathrm{W}\right)$ was obtained from the NCEP-NARR node at http://www.cgd.ucar. edu/cas/catalog/climind/index.html (Messinger et al., 2006).

\subsection{Data analysis}

The in-situ data of air temperature and relative humidity from Tuxpan and Veracruz were compared with the model data using a mean squared error:

$M S E=\sqrt{\frac{\sum_{i=1}^{N}\left(y_{i}-x_{i}\right)^{2}}{N}}$

where $y_{\mathrm{i}}$ and $x_{\mathrm{i}}$ are the data from each time series and $N$ is the number of observations of the time series. Descriptive statistics (mean and standard deviation) and the MSE comparing the air temperature and relative humidity time series are shown in Table I for Tuxpan and Veracruz and in Figure 1 of the supplementary material (Fig. SM-1).

Although no in situ rainfall data was available, several studies have shown that the NCEP-NARR rainfall data is reliable at local scales (Kalnay et al., 1996; Nieto et al., 2004; Messinger et al., 2006; Tolika et al., 2006; Ruane, 2010; Salas-Pérez and González-Gándara, 2016). In this study, the time series of the Bermuda Index is computed from daily mean sea level pressure at $32^{\circ} \mathrm{N}, 66^{\circ} \mathrm{W}$, minus the Tuxpan reefs $\left(20.999^{\circ} \mathrm{N}\right.$, $\left.97.348^{\circ} \mathrm{W}\right)$, Veracruz $\left(19.285^{\circ} \mathrm{N}, 96.208^{\circ} \mathrm{W}\right)$ and Coatzacoalcos $\left(18.248^{\circ} \mathrm{N}, 94.465^{\circ} \mathrm{W}\right)$.

To understand local climate variability related to large-scale processes, the time series of air temperature, relative humidity and rainfall were correlated with time series of the NASH through a wavelet coherence analysis with zero-time lag (Grinsted et al., 2004). Wavelet coherence allows investigating the temporal variation of the correlation between two signals in a cross-spectral density diagram. A near-zero coherence indicates no linear relationship between the series while a value close to 1 indicates linear relationship (Labat et al., 2005). The period and time of occurrence of significant coherence are depicted by a thick black line in the wavelet maps. Also, arrows within the contour lines indicate if the series were in phase (arrows pointing right), anti-phase (arrows pointing left), or if one series is lead by $90^{\circ}$ (arrows pointing down) or vice versa (arrows pointing up). The analysis was done using Matlab (2017).

Seasonal means from the daily time series of air temperature, relative humidity, and rainfall were calculated and then anomalies were obtained for each time series ( $i$ ) using Eq. (2):

$a_{i t}=x_{i t}-\bar{x}_{i}$ 
Table I. Mean values ( \pm standard deviation) and mean squared error (MSE) of in situ and modeled (NCEPNARR) data for Tuxpan and Veracruz.

\begin{tabular}{lccccc}
\hline & $\begin{array}{c}\text { Tuxpan } \\
\text { (in situ) }\end{array}$ & $\begin{array}{c}\text { Tuxpan } \\
\text { (modeled) }\end{array}$ & $\begin{array}{c}\text { Veracruz (in } \\
\text { situ) }\end{array}$ & $\begin{array}{c}\text { Veracruz } \\
\text { (modeled) }\end{array}$ & $\begin{array}{c}\text { Tuxpan, Vercaruz } \\
\text { (MSE) }\end{array}$ \\
\hline Air temperature $\left({ }^{\circ} \mathrm{C}\right)$ & $24.27 \pm 2.44$ & $23.99 \pm 3.08$ & $25.44 \pm 2.15$ & $24.12 \pm 2.21$ & $2.89 \pm 1.15$ \\
\hline Relative humidity $(\%)$ & $77.24 \pm 9.62$ & $78.24 \pm 9.62$ & $75.19 \pm 8.43$ & $78.19 \pm 8.43$ & $0.90 \pm 2.85$ \\
\hline
\end{tabular}

where $a_{i t}$ is the anomaly of series $i$ at time $\mathrm{t}, x_{i t}$ is a datum of series $i$ at time $\mathrm{t}$, and $\overline{x_{i}}$ is the mean of the time series (Salas-Pérez and González-Gándara, 2016).

The maximum positive and negative seasonal climate anomalies per year were selected to from annual minima and maxima time series:

$Y_{\text {maxsummeri }}=\max \left(a_{i \text { summer }}\right)$

$Y_{\text {minwinteri }}=\operatorname{mix}\left(a_{i \text { winter }}\right)$

where $Y_{\text {maxsummeri }}$ and $Y_{\text {minwinteri }}$ represent the maximum values of positive and negative anomalies selected to form the $i$ annual time-series.

Linear trends for each maximum positive and negative time series anomalies were estimated using a generalized least squares regression that accounts for autocorrelation in the residual series (Cowpertwait and Metcalfe, 2009). The analysis was done using the "nlme" library (Pinheiro et al. 2016) in R (R Core Team, 2016).

Using the maximum positive and negative data of the seasonal climate anomalies, two new yearly times series were constructed. These time series depict the extreme anomalies that occurred during the summer (positive, maxima) and winter (negative, maxima) for the 35-year data set. These extremes were modeled using a generalized extreme value distribution following the block maximum approach with the "extRemes" library (Gilleland and Katz, 2014). To capture spatial variation, an extreme value distribution was fit to positive and negative maximum anomalies time series by location (Murphy et al., 2004; Cooley, 2009). Model fitting was assessed using quantile-quantile and density plots (Gilleland and Katz, 2014), and the probability that annual minima or maxima exceeded the 75 percentiles of each series was estimated (Tank et al., 2009).

\section{Results}

The annual cycle in this region is characterized by a cold and dry winter, with increasing temperature and humidity during spring, reaching a maximum in summer and decreasing again in fall (Salas-Pérez and Granados-Barba, 2008; Salas-Pérez and Jordán-Garza, 2018). The mean for each climate variable followed this seasonal pattern at the three locations, but rainfall data showed higher variability than air temperature and relative humidity (Fig. 3, based on modeled data).

Climate anomalies followed a similar annual pattern as the mean climatic series, with negative anomalies predominating on winter and fall and positive on spring and summer; variability was larger for rainfall anomalies (Fig. 4).

\subsection{Results from the Bermuda High Index}

Bermuda High Index computed at the reef locations of this study, showed positive values indicating its influence on climate variability (Fig. 5). Note the similarity between time series (which have multi-annual fluctuations) due to the influence of the NASH over the relatively small area where the three locations are situated.

\subsection{Coherence with the Bermuda High pressure system} The three climate variables showed significant coherence at different periods and years with the North Atlantic High-pressure System at the three locations (Fig. 6).

Significant coherence at periods of approximately 4 years was common to the three variables and on the three locations (Fig. 6). The arrows within the significant coherence pointed up or were inclined to 

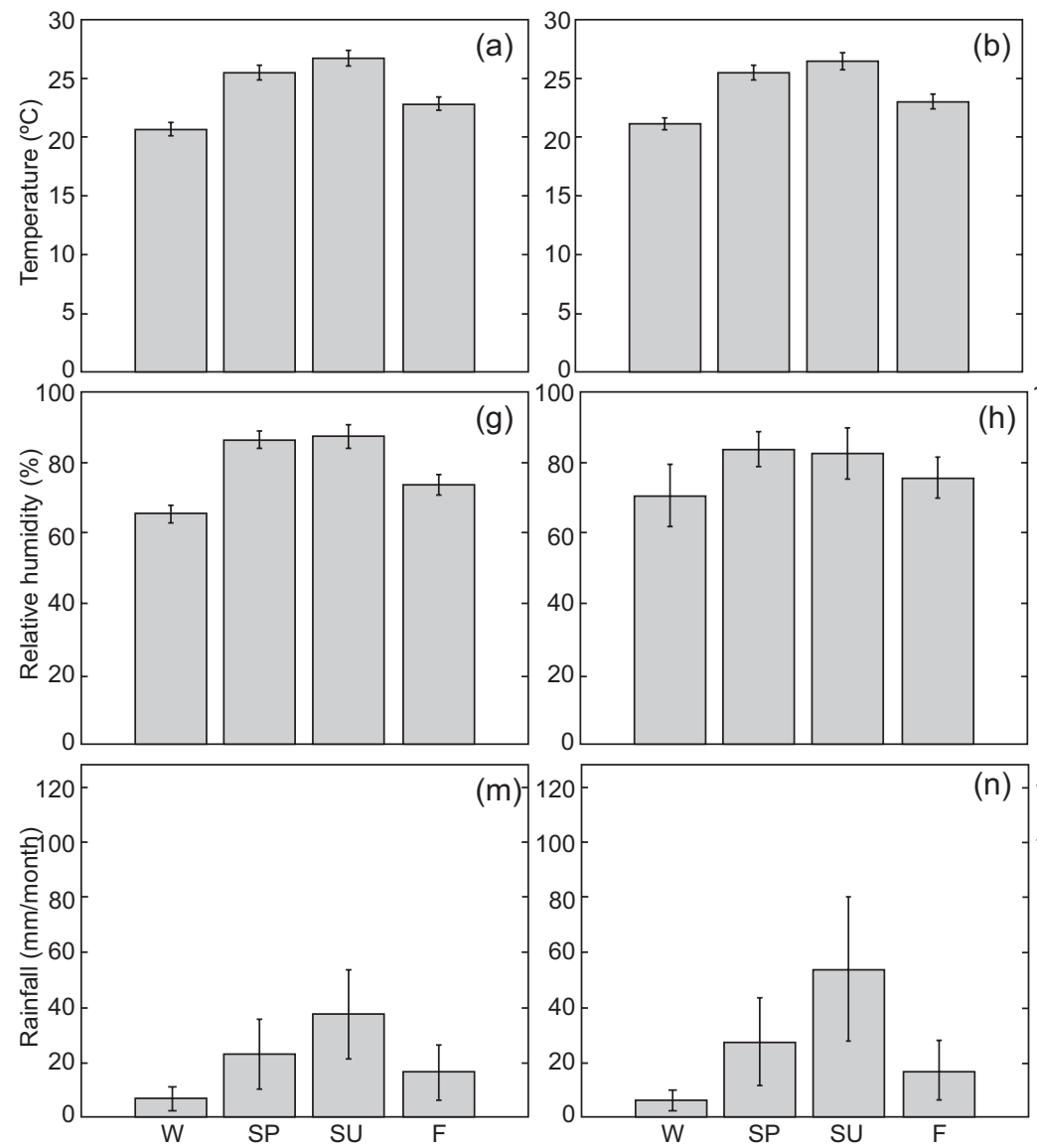

(b)

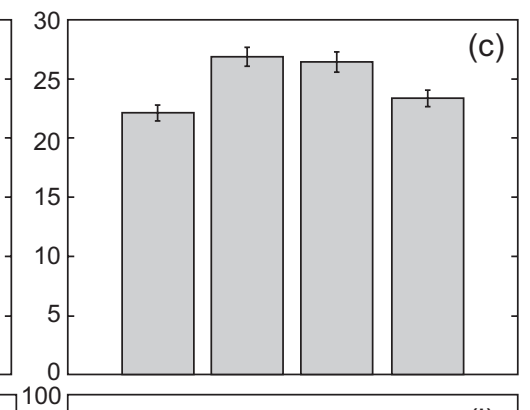

(h)
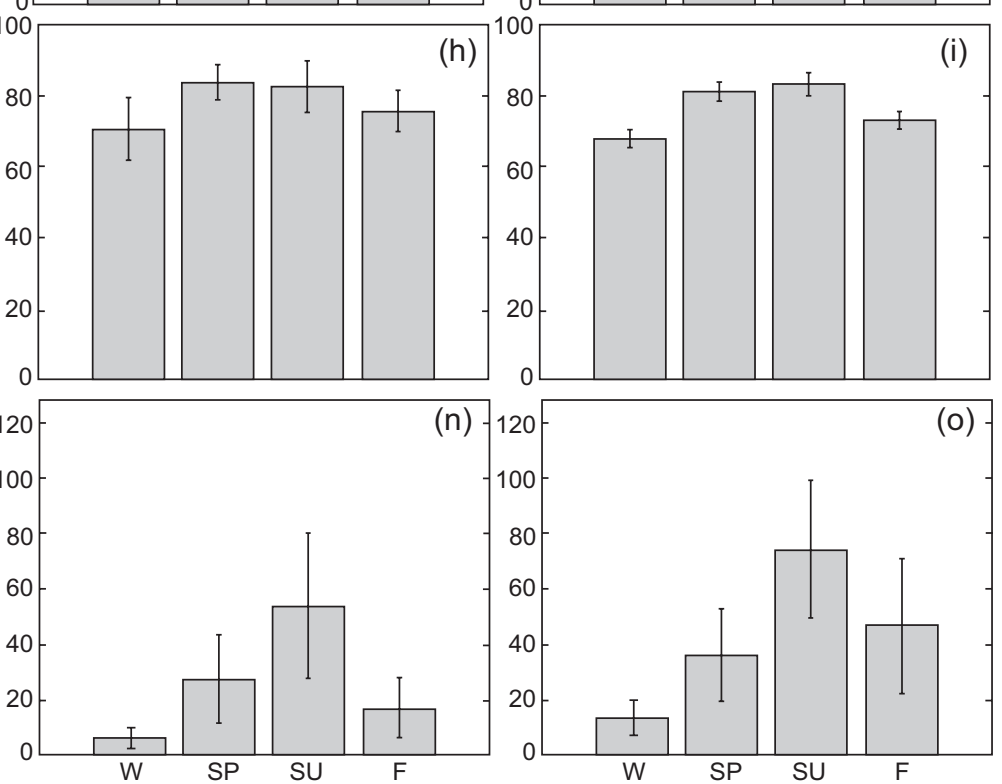

Fig. 3. Mean 35-year seasonal patterns for air temperature, relative humidity and rainfall at the three locations: (a, g, m) Tuxpan, (b, h, n) Veracruz, and (c, i, o) Coatzacoalcos. Bars show means and whiskers show 95\% confidence intervals.

the right, suggesting that the changes in the climate variables occurred slightly before or at the same time as the changes of atmospheric pressure at mean sea level (Bermuda High pressure oscillation) (Fig. 6). A similar pattern occurred with significant coherence between the signals at periodicities of $8+$ years, particularly in Coatzacoalcos, the southern location (Fig. 6 c, i).

\subsection{Linear trends in minimum and maximum ano- malies}

In general, climate anomalies of all three variables (air temperature, relative humidity, and rainfall) showed similar trends at the three locations for the studied period (Table II). Maximum anomalies of air temperature showed significant increasing trends in the northern and central locations and minimum anomalies showed a significant increasing trend at the southern location (Table II). Maximum anomalies of relative humidity showed significant increasing trends at all locations and minimum anomalies showed no significant trends (Table II). Maximum rainfall anomalies showed a significant increasing trend only at the central location, and minimum anomalies showed no significant trends (Table II).

\subsection{Extreme values}

For all cases, the quantile-quantile plots and density plots showed a reasonable model fit (Gilleland and Katz, 2014). In general, the return level of maximum positive and negative anomalies followed a gradually decreasing trend with the return period, except for negative anomalies of rainfall at Tuxpan and Veracruz (see Fig. 7 for Tuxpan and supplementary Fig. SM-5). 

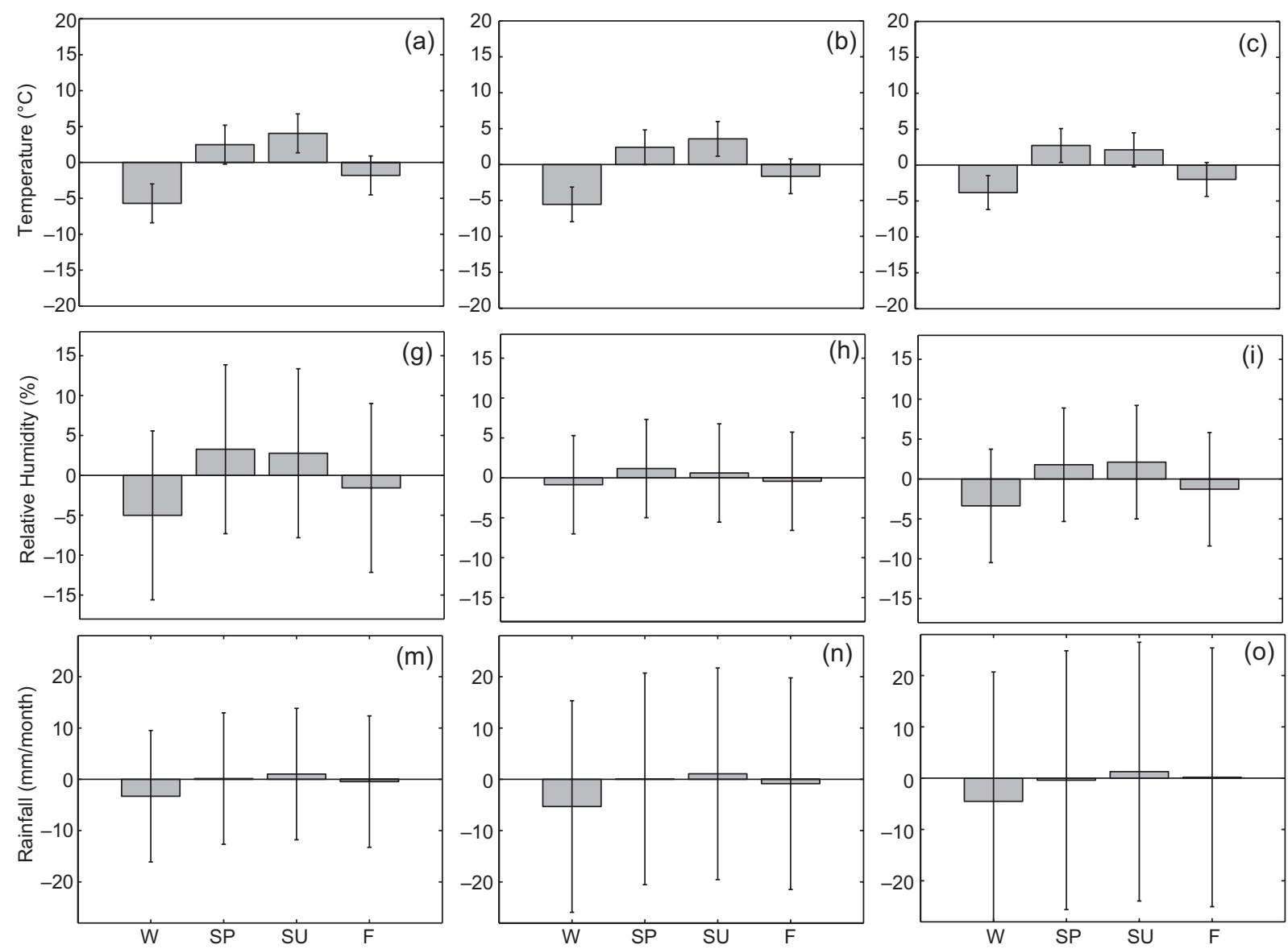

Fig. 4. Mean 35-year annual patterns for anomalies of air temperature, relative humidity and rainfall at the three locations: (a, g, m) Tuxpan, (b, h, n) Veracruz, (c, i, o) Coatzacoalcos. Bars show means and whiskers show 95\% confidence intervals.
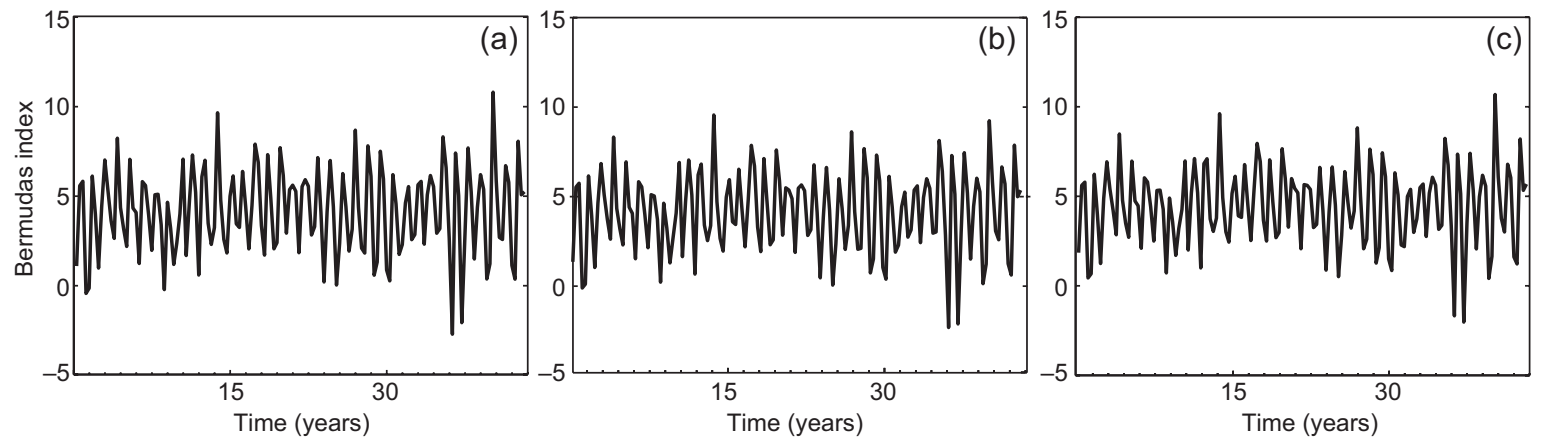

Fig. 5. Bermuda High Index at reef locations. The local index was computed as the difference of the Bermuda High and the pressure at mean sea level over the reef systems. (a) Tuxpan, (b) Veracruz, (c) Coatzacoalcos. The positive values indicate the influence of the Bermuda High over the reef locations. 

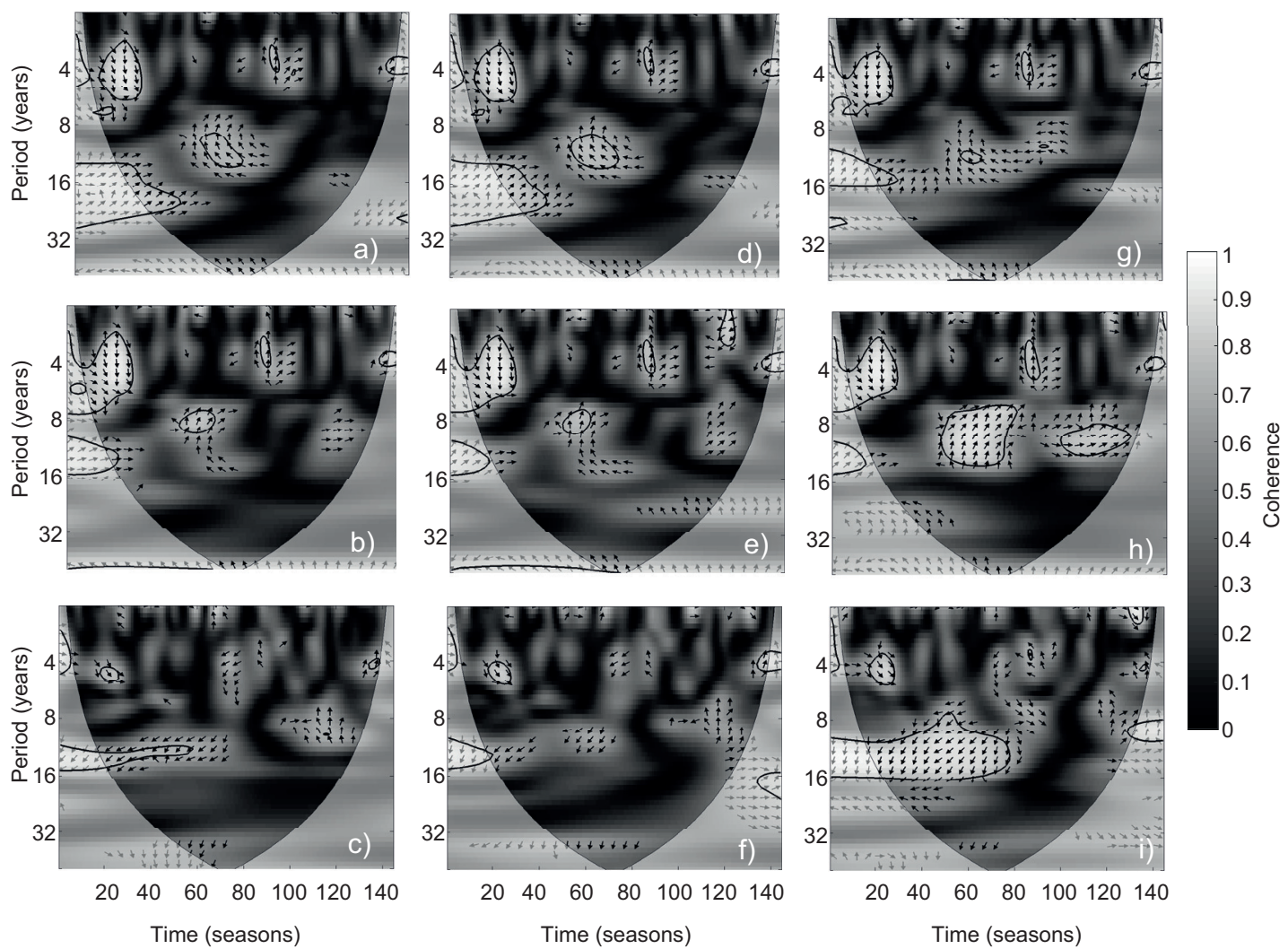

Fig. 6. Wavelet coherence of air temperature, relative humidity and rainfall with the Bermuda High Index. $(a, b, c)$ At the Tuxpan location; (d, e, f) at the Veracruz location; $(g, h, i)$ at the Coatzacoalcos location. Black contours show significant coherence at the $95 \%$ confidence. The gray scale shows coherence values.

The thresholds for each anomaly were chosen using the 75th percentile for each variable and each location. The probability of exceeding these thresholds was calculated for each variable and location; in all cases, it was $>0.5$ (Table III).

The correlation between anomalies of the three meteorological variables with ENSO, NAO and AMO indexes is shown in the supplementary information (Figs. SM-3 and SM-4). It is observed that correlation coefficients of the ENSO and NAO indexes with anomalies are lower ( -0.4 to 0.4$)$ than with the AMO index $(>0.5)$ and, in some cases, negative. Thus, the correlation with the Bermuda High Index appears to dominate. However, in Figure 8 the AMO index had correlation coefficients $>0.5$ and significant $(p=0.001)$. Hence, both the $\mathrm{NASH}$ and the AMO can potentially affect climate variability over the reef corridor of the southwestern Gulf of Mexico.

\section{Discussion and conclusions}

All climate variables at the three locations along the reef corridor of the southwestern Gulf of Mexico showed significant coherence with the Bermuda High pressure index at periods from 4 to 8 years, and only for air temperature and relative humidity, at multidecadal ( $>16$ years) periods. Climate variability has been related to changes in the atmospheric fluxes of heat and rain that can occur over large spatial scales and different temporal scales (Marshall et al., 2001). These periods of significant coherence for climate variables suggest the modulation of different atmospheric phenomena that can act through teleconnections (Sheridan, 2003). For example, ENSO, NAO, and AMO could influence interannual to interdecadal scales (Jin and Kirtman, 2010; Zhu and Liang, 2013) (see Figs. SM-3 and SM-4).

The influence of the synoptic-scale circulations can generate short-term (a few days) up to seasonal 
Table II. Linear trends for climate anomalies (maximum and minimum) at the three locations along Veracruz*.

\begin{tabular}{|c|c|c|c|c|}
\hline Anomalies & Location & Slope & p-value & $\begin{array}{l}\text { Differences between } \\
\text { locations }\end{array}$ \\
\hline $\begin{array}{l}\text { Air temperature } \\
\left(\max ,{ }^{\circ} \mathrm{C} / \text { year) }\right.\end{array}$ & $\begin{array}{l}\text { Tuxpan } \\
\text { Veracruz } \\
\text { Coatzacoalcos }\end{array}$ & $\begin{array}{l}\mathbf{0 . 0 3}(\mathbf{0 . 0 0 0 7}, \mathbf{0 . 0 5}) \\
\mathbf{0 . 0 3}(\mathbf{0 . 0 1}, \mathbf{0 . 0 5}) \\
0.02(-0.004,0.05)\end{array}$ & $\begin{array}{l}\mathbf{0 . 0 1} \\
\mathbf{0 . 0 0 7} \\
0.1\end{array}$ & $\begin{array}{l}\text { Tuxpan }= \\
\text { Veracruz }> \\
\text { Coatzacoalcos }\end{array}$ \\
\hline $\begin{array}{l}\text { Air temperature } \\
\left(\mathrm{min},{ }^{\circ} \mathrm{C} / \text { year }\right)\end{array}$ & $\begin{array}{l}\text { Tuxpan } \\
\text { Veracruz } \\
\text { Coatzacoalcos } \\
\end{array}$ & $\begin{array}{l}0.01(-0.004,0.03) \\
0.01(-0.0015,0.03) \\
\mathbf{0 . 0 2}(\mathbf{0 . 0 0 2}, \mathbf{0 . 0 4})\end{array}$ & $\begin{array}{l}0.15 \\
0.08 \\
\mathbf{0 . 0 3}\end{array}$ & $\begin{array}{l}\text { Tuxpan }= \\
\text { Veracruz }< \\
\text { Coatzacoalcos }\end{array}$ \\
\hline $\begin{array}{l}\text { Relative humidity } \\
(\max , \% / \text { year) }\end{array}$ & $\begin{array}{l}\text { Tuxpan } \\
\text { Veracruz } \\
\text { Coatzacoalcos } \\
\end{array}$ & $\begin{array}{l}0.13(0.05,0.22) \\
0.14(0.05,0.24) \\
0.16(0.06,0.26)\end{array}$ & $\begin{array}{l}0.048 \\
0.005 \\
0.002 \\
\end{array}$ & $\begin{array}{l}\text { Tuxpan }= \\
\text { Veracruz }= \\
\text { Coatzacoalcos }\end{array}$ \\
\hline $\begin{array}{l}\text { Relative humidity } \\
\text { (min, \%/year) }\end{array}$ & $\begin{array}{l}\text { Tuxpan } \\
\text { Veracruz } \\
\text { Coatzacoalcos }\end{array}$ & $\begin{array}{l}0.003(-0.07,0.07) \\
0.025(-0.04,0.08) \\
0.06(-0.01,0.13)\end{array}$ & $\begin{array}{l}0.93 \\
0.43 \\
0.09\end{array}$ & $\begin{array}{l}\text { Tuxpan }= \\
\text { Veracruz }= \\
\text { Coatzacoalcos }\end{array}$ \\
\hline $\begin{array}{l}\text { Rainfall (max, } \\
\text { mm/month.year) }\end{array}$ & $\begin{array}{l}\text { Tuxpan } \\
\text { Veracruz } \\
\text { Coatzacoalcos }\end{array}$ & $\begin{array}{l}0.21(-0.4,0.8) \\
\mathbf{0 . 9 8}(\mathbf{0 . 0 0 3}, \mathbf{1 . 9}) \\
0.83(-0.005,1.72)\end{array}$ & $\begin{array}{l}0.49 \\
\mathbf{0 . 0 5} \\
0.07\end{array}$ & $\begin{array}{l}\text { Tuxpan }< \\
\text { Veracruz }> \\
\text { Coatzacoalcos }\end{array}$ \\
\hline $\begin{array}{l}\text { Rainfall (min, } \\
\mathrm{mm} / \text { month.year) }\end{array}$ & $\begin{array}{l}\text { Tuxpan } \\
\text { Veracruz } \\
\text { Coatzacoalcos }\end{array}$ & $\begin{array}{l}-0.017(-0.11,0.07) \\
-0.12(-0.25,0.006) \\
-0.11(-0.25,0.03)\end{array}$ & $\begin{array}{l}0.7 \\
0.07 \\
0.13\end{array}$ & $\begin{array}{l}\text { Tuxpan }= \\
\text { Veracruz }= \\
\text { Coatzacoalcos }\end{array}$ \\
\hline
\end{tabular}

*Figures are the result of a generalized least squares regression showing the slope (representing the linear trend), its $95 \%$ confidence interval, and significance (p-value). Differences between locations were based on the slope significance and represent which location experiences similar $(=)$, larger $(>)$ or smaller $(<)$ change between each other.

fluctuations in air temperature, relative humidity, and rainfall at the study area (Salas-Pérez and Granados-Barba, 2008; Salas-Pérez and Arenas-Fuentes, 2011) (Fig. SM-1). Several synoptic-scale phenomena, like tropical waves, and tropical cyclones can locally increase the amount of rainfall in the western Gulf of Mexico (Tejeda-Martínez and Welsh-Rodríguez, 2006). It is not clear if the shortest meteorological scales can influence the seasonal scales on an interannual basis (Gutiérrez de Velasco and Winant, 1996). But a previous study on the north location of the reef corridor (Fig. 2) showed that teleconnections like the ENSO inter-annual signal have an impact on rainfall fluctuations in the study area (Salas-Pérez and González-Gándara, 2016; Díaz-Esteban and Raga, 2018).

Stahle and Cleaveland (1992) measured the influence of NASH on the southern United States and southwestern North Atlantic, through the pressure gradient across their study area. Their results showed positive values, indicating that the western edge of the Bermuda High was located farther east than its normal position (Katz et al., 2003), which may correspond to enhanced southerly moisture advection and reduced stability of the atmospheric layer over the southeast United States (Henderson and Vega, 1996). In this context, the coherence phase arrows of the pressure at mean sea level of the Bermuda High and the meteorological variables in the reef corridor of the southwestern Gulf of Mexico showed that, in general, atmospheric pressure at mean sea level was leading changes in air temperature, relative humidity and rainfall in periods of 4 to 8 years, which could be related to the ENSO signal affecting the study area (Salas-Pérez and Gónzalez-Gandara, 2016). A multidecadal signal affecting mainly air temperature could be related to AMO and its effects to the increased variability in rainfall over the region (Fig. 8). 

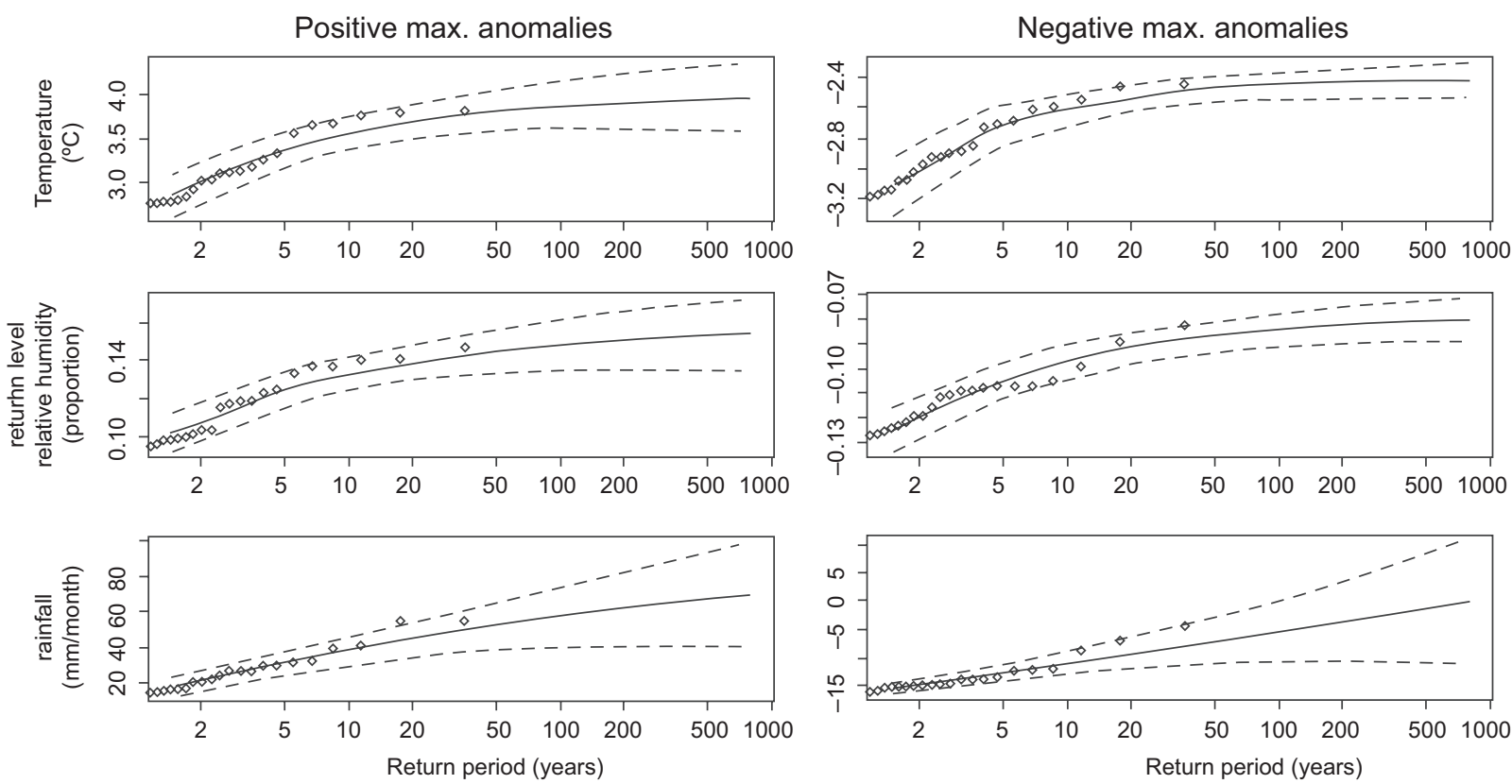

Fig. 7. Return-level plots of maximum positive and negative climate anomalies at Tuxpan. The solid lines show the associated general extreme value distribution and the dotted lines the $95 \%$ confidence intervals. Note different values on the $y$-axes. Similar patterns were observed at the other locations (see Fig. SM-5a, b).

Table III. Estimated probabilities of exceeding an anomaly threshold for the observed dataset.

\begin{tabular}{llcc}
\hline Climate anomalies & Location & $\begin{array}{c}75 \\
\text { percentile }\end{array}$ & $\begin{array}{c}\text { Probability of exceeding } \\
\text { the } 75 \text { percentile }\end{array}$ \\
\hline $\begin{array}{llcc}\text { Positive maximum } \\
\text { air temperature }\left({ }^{\circ} \mathrm{C} / \text { year}\right)\end{array}$ & Tuxpan & 3.15 & 0.68 \\
& Veracruz & 2.77 & 0.7 \\
& Coatzacoalcos & 3.87 & 0.98 \\
\hline Negative maximum air & Tuxpan & -2.87 & 0.69 \\
temperature $\left({ }^{\circ} \mathrm{C} /\right.$ year) & Veracruz & -2.12 & 0.98 \\
& Coatzacoalcos & -1.41 & 0.99 \\
\hline Positive maximum & Tuxpan & 11.8 & 0.73 \\
relative humidity (\%/year) & Veracruz & 12.9 & 0.98 \\
& Coatzacoalcos & 9.84 & 0.81 \\
\hline Negative maximum & Tuxpan & -10.93 & 0.74 \\
relative humidity (\%/year) & Veracruz & -7.4 & 0.99 \\
& Coatzacoalcos & -6.74 & 0.78 \\
\hline Positive maximum rainfall & Tuxpan & 26.58 & 0.73 \\
(mm/month.year) & Veracruz & 47.38 & 0.75 \\
& Coatzacoalcos & 49.02 & 0.74 \\
\hline Negative maximum rainfall & Tuxpan & -14.03 & 0.69 \\
(mm/month.year) & Veracruz & -6.01 & 0.99 \\
& Coatzacoalcos & -27.89 & 0.72 \\
\hline
\end{tabular}



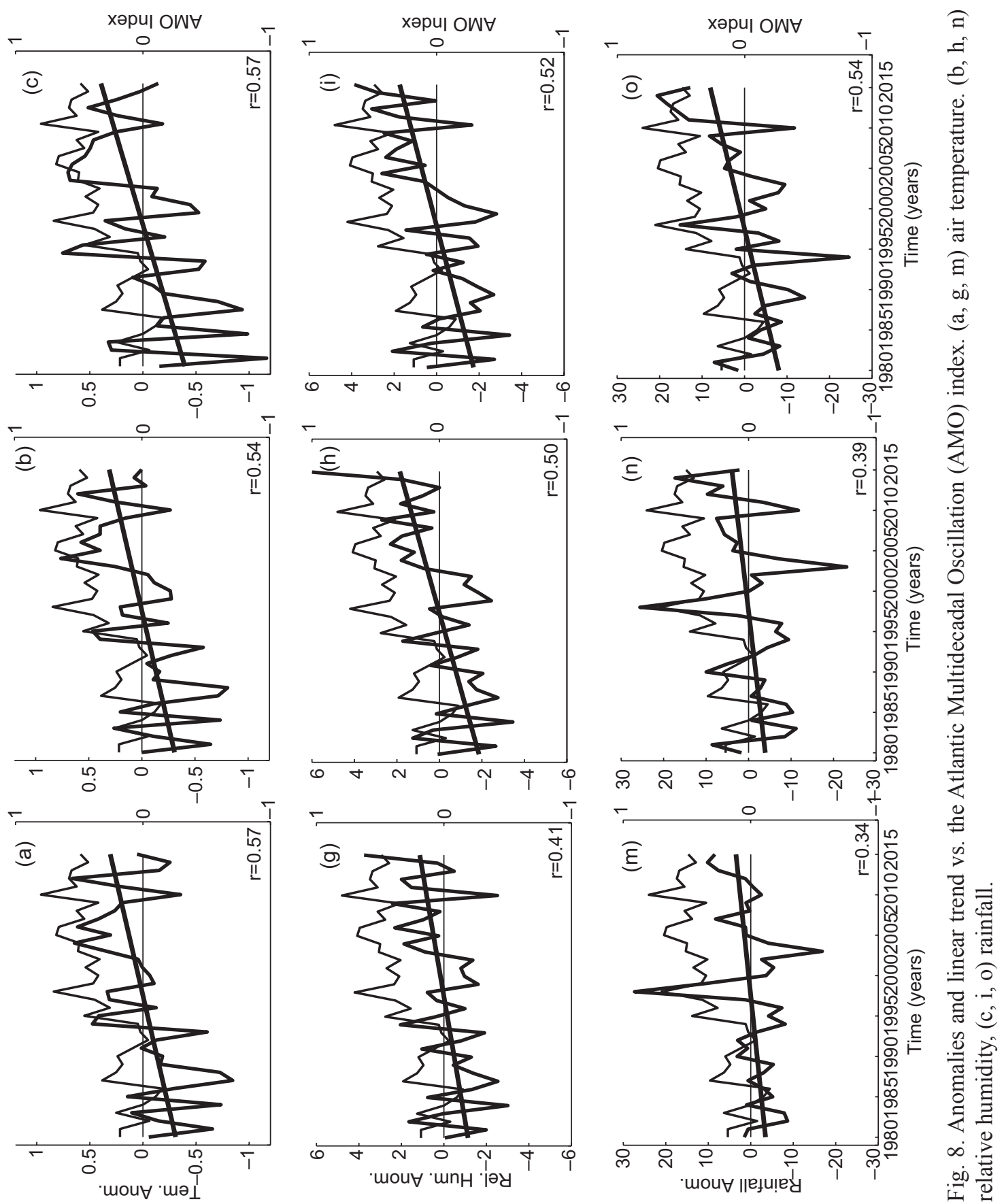

Enfield et al. (2001) showed that during the warm phase of AMO rainfall was minimum in the United States and it increased during the transition to a cold AMO phase.

Positive anomalies of air temperature showed significant increasing trends except in Coatzacoal$\cos$ (southern location), where negative anomalies became warmer. These patterns depict a future increase of positive temperature anomalies in spring and summer at the central and northern locations and milder cold anomalies in winter and fall at the southern location. These trends are following the general warming of sea surface temperature that has been observed in other regions of the Gulf of 
Mexico (Kuffner et al., 2015). Winter cooling and warming have also been reported (Chollett et al., 2012), and the latter has facilitated a range expansion of coral species to northern latitudes in Florida (Precht and Aronson, 2004). Yet, these warming patterns are expected to cause important changes in the ecology of the reef systems in the study area (Walther et al., 2002; Bruno et al., 2007; Heron et al., 2010; Ruiz-Moreno et al., 2012). Positive relative humidity anomalies showed a significant trend at the three locations, just like positive rainfall anomalies did at the central location. These patterns depict moister spring and summer conditions in the region that can potentially increase the risk of floods in the area (Milly et al., 2002), which could be related to teleconnections, mainly with the AMO mode. It is known that when the Bermuda High approaches the Gulf of Mexico, rain amounts increase, and when the Bermuda High moves away, then rain amounts decrease at interannual and decadal scales (Kucharski et al., 2010).

We acknowledge that the data set analyzed encompasses a relatively short period (1980 to 2015), so the significant trend of warmer air temperature anomalies is not surprising. Historical reconstructions of global air temperature have shown that, since 1880 , global mean temperature has increased about $0.85 \pm 0.2{ }^{\circ} \mathrm{C}$ (Easterling et al., 1997; Reynolds et al., 2008; Wiles et al., 2014; IPCC, 2014). This warming could, in turn, influence changes in relative humidity and rainfall, as the three climate variables are highly correlated (Table SM-I). An interesting observation is the increase of positive anomalies regarding relative humidity at the three locations of the study area. As temperature increases, so does saturated vapor pressure, and relative humidity should decrease or remain constant, but only if vapor pressure remains the same or increases at a lower rate than temperature, which could be the result of the relative short time-series analyzed in this study.

The coherence of the pressure at mean sea level of the Bermuda High pressure system with the raw meteorological time-series showed variability consistent with well-known modes such as ENSO, NAO, and AMO. Positive and negative anomalies showed low correlation values $(-0.4$ to 0.4$)$ with the ENSO and NAO modes while correlations were high $(>0.5)$ and significant with the AMO mode. Therefore, the results indicate that both the Bermuda High and the AMO modes modulate the climatic variability of the reef corridor in the southwestern Gulf of Mexico.

\section{Acknowledgments}

We acknowledge the Servicio Meteorológico Nacional of Mexico (CONAGUA) for providing the meteorological in situ data set used in this research. We appreciate the work done with the database of the NCEP-NARR model by the following B.Sc. in Marine Biology: Ángel N. Ocaña-Valencia, Isis Angélica Ortégon-Burgos and Marian Soto Razeola. Also, we thank the reviewers and editor for the comments that improved this manuscript.

\section{Supplementary material}

Suplemmentary material is available at: https://www. revistascca.unam.mx/atm/SupplementaryMaterial/52730-Salas-SupMat.pdf

\section{References}

Adger WN, Arnell NW, Tompkins EL. 2005. Successful adaptation to climate change across scales. Global Environmental Change 15(2):77-86.

DOI: 10.1016/j.gloenvcha.2004.12.005

Bruno JF, Selig ER, Casey KS, Page CA, Willis BL. 2007.

Thermal stress and coral cover as drivers of coral disease outbreaks. PLoS One 5(6):e124.

DOI: 10.1371/journal.pbio.0050124

Carricart-Ganivet JP, Merino M. 2001. Growth responses of the reef-building coral Montastraea annularis along a gradient of continental influence in the southern Gulf of Mexico. Bulletin of Marine Science 68(1):133-146.

Chollett I, Müller-Karger FE, Heron SF, Skirving W and Mumby PJ. 2012. Seasonal and spatial heterogeneity of recent sea surface temperature trends in the Caribbean Sea and southeast Gulf of Mexico. Marine Pollution Bulletin 64(5):956-965.

DOI: 10.1016/j.marpolbul.2012.02.016

Cooley D. 2009. Extreme value analysis and the study of climate change. Climatic Change 97(1):77-83.

DOI: $10.1007 / \mathrm{s} 10584-009-9627-\mathrm{x}$

Cowpertwait PS, Metcalfe AV. 2009. Introductory time series with $R$. Springer-Verlag, New York, 256 pp. DOI: $10.1007 / 978-0-387-88698-5$ 
Díaz-Esteban Y, Raga GB. 2018. Weather regimes associated with summer rainfall variability over southern Mexico. International Journal of Climatology 38(1):169-186.

DOI:10.1002/joc.5168

Easterling DR, Horton B, Jones PD, Peterson TC, Karl TR. 1997. Maximum and minimum temperature trends for the globe. Science 277(5324):364-367.

DOI: $10.1126 /$ science. 277.5324 .364

Enfield DB, Mestas-Núñez AM, Trimble PJ. 2001. The Atlantic multidecadal oscillation and its relation to rainfall and river flows in the continental US. Geophysical Research Letters 28(10):2077-2080.

DOI: 10.1029/2000GL012745

Gilleland E, Katz RW. 2014. extRemes 2.0: An extreme value analysis package in R. Journal of Statistical Software 72(8):1-39.

DOI: 10.18637 jss.v072.i08

Grinsted A, Moore JC, Jevrejeva S. 2004. Application of the cross wavelet transform and wavelet coherence to geophysical time series. Nonlinear Processes Geophysics 11:561-566.

DOI: /10.5194/npg-11-561-2004

Gutiérrez de Velasco G, Winant CD. 1996. Seasonal patterns of wind stress and wind stress curl over the Gulf of Mexico. Journal Geophysical Research 101:1812718140. DOI: 10.1029/96JC01442

Henderson KG, and Vega AJ. 1996. Regional precipitation variability in the southern United States. Physical Geography 17:93-112.

DOI: $10.1080 / 02723646.1996 .10642576$

Hoegh-Guldberg O, Mumby PJ, Hooten AJ, Steneck RS, Greenfield P, Gomez E, Harvell CD, Sale PF, Edwards AJ, Caldeira K, Knowlton N, Eakin CM, Iglesias-Prieto R, Muthiga N, Bradbury RH, Dubi1 A, Hatziolos ME. 2007. Coral reefs under rapid climate change and ocean acidification. Science 318(5857):1737-1742.

DOI: $10.1126 /$ science. 1152509

Heron SF, Willis BL, Skirving, WJ, Eakin CM, Page CA. 2010. Summer hot snaps and winter conditions: modelliNg white syndrome outbreaks on Great Barrier Reef corals. PLoS One. 5(8): e12210.

DOI: 10.1371 journal.pone.0012210

INEGI. 2010. Censo de Población y Vivienda. Instituto Nacional de Estadística y Geografía, Mexico. Available at: https://www.inegi.org.mx/programas/ ccpv/2010/
IPCC. 2014. Synthesis report. Contribution of Working Groups I, II and III to the Fifth Assessment Report of the Intergovernmental Panel on Climate Change. In: Climate Change 2014 (Pachauri RK, Meyer LA, Eds.). Intergovernmental Panel on Climate Change, Switzerland.

Jiménez-Badillo L. 2007. Management challenges of small-scale fishing communities in a protected reef system of Veracruz, Gulf of Mexico. Fisheries Management Ecology 15(1):19-26.

DOI: $10.1111 / \mathrm{j} .1365-2400.2007 .00565 . x$

Jordán-Dahlgren E, Rodríguez-Martínez RE. 2003. The Atlantic coral reefs of Mexico. Latin American Coral Reefs 1:131-158.

DOI: 10.1016/B978-044451388-5/50007-2

Jordán-Garza AG, González-Gándara C, Salas-Pérez JJ, Morales-Barragán AM. 2017. Coral assemblages are structured along a turbidity gradient on the Southwestern Gulf of Mexico, Veracruz. Continental Shelf Research 138:32-40. DOI: 10.1016/j.csr.2017.03.002

Jin D, Kirtman BP. 2010. How the annual cycle affects the extratropical response to ENSO. Journal of Geophysical Research Atmospheres 115(D6):2500-2527. DOI: 10.1029/2009JD012660

Kalnay E, Kanamitsu M, Kistler R, Collins W, Deaven D, Gandin L, Iredell M, Saha S, White G, Woollen J, Zhu Y, Chelliah M, Ebisuzaki W, Hoy, Joseph D. 1996. The NCEP-NCAR 40-year reanalysis project. Bulletin of the American Meteorological Society 77(3): 437-471. DOI: $10.1175 / 1520-0477(1996) 077<0437$ :TNYRP $>2.0 . \mathrm{CO} ; 2$

Katz RW, Parlange MB, Tebaldi C. 2003. Stochastic modeling of the effects of large-scale circulation on daily weather in the southeastern. U.S. Climatic Change 60:189-216.

DOI. 10.1023/A:1026054330406

Kucharski F, Kang I-S, Straus D, King MP. 2010. Teleconnections in the atmosphere and oceans. American Meteorological Society 91(3):381-383. DOI: $10.1175 / 2009 B A M S 2834.1$

Kuffner IB, Lidz BH, Hudson JH and Anderson JS. 2015. A century of ocean warming on Florida Keys coral reefs: historic in situ observations. Estuaries and Coasts 38(3):1085-1096. DOI: 10.1007/s12237-014-9875-5

Labat D, Ronchail J, Guyot JL. 2005. Recent advances in wavelet analyses: Part 2 - Amazon, Parana, Orinoco and Congo discharges time scale variability. Journal of Hydrology 314(1):289-311.

DOI: $10.1016 /$ j.jhydrol.2005.04.004 
Li W, Li L, Fu R, Deng Y, Wang H. 2011. Changes to the North Atlantic subtropical high and its role in the intensification of summer rainfall variability in the southeastern United States. J. Climate. 24:1499-1506. DOI: 10.1175/2010JCLI3829.1

Marshall J, Kushnir Y, Battisti D, Chang P, Czaja A, Dickson R, Visbeck M. 2001. North Atlantic climate variability: Phenomena, impacts and mechanisms. International Journal of Climatology 21(15):1863-1898. DOI: $10.1002 /$ joc.693

Matlab. 2017. MathWorks. Policies and statements. Available at: https://a.mathworks.com/company/aboutus/ policies_statements/patents.html?s_tid=gf_pat

Mendoza-Cantú A, Heydrich SC, Cervantes IS, Orozco O. 2011. Identification of environmentally vulnerable areas with priority for prevention and management of pipeline crude oil spills. Journal of Environmental Management 92(7):1706-1713.

DOI: 10.1016/j.jenvman.2011.02.008

Mesinger F, Dimego G, Kalnay E, Mitchell K, Shafran PC. 2006. North American Regional Reanalysis. Bulletin of the American Meteorologic Society 87:343-360. DOI: 10.1175/BAMS-87-3-343.

DOI: $10.1175 /$ BAMS-87-3-343

Milly PCD, Wetherald RT, Dunne KA, Delworth TL. 2002. Increasing risk of great floods in a changing climate. Nature 415(6871):514-517. DOI: 10.1038/415514a

Moberg F, Folke C. 1999. Ecological goods and services of coral reef ecosystems. Ecological Economics 29(2):215-233.

DOI: 10.1016/S0921-8009(99)00009-9

Murphy JM, Sexton DMH, David N, Barnett DN, Jones GS. 2004. Quantification of modelling uncertainties in a large ensemble of climate change simulations. Nature 430:768-772.

DOI: $10.1038 /$ nature 02771

Nieto S, Frías MD, Rodríguez-Puebla C. 2004. Assessing two different climatic models and the NCEP-NCAR reanalysis data for the description of winter precipitation in the Iberian Peninsula. International Journal of Climatology 24:361-376.

DOI: 10.1002/joc.999

Ortegren JT, Knapp PA, Maxwell JT, Tyminski WP, Soule PT. 2011. Ocean-atmosphere influences on low frequency warm-season drought variability in the Gulf Coast and southeastern United States. Journal of Applied Meteorology and Climatology 50:1177-1186. DOI: 10.1175/2010JAMC2566.1
Palumbi SR, Barshis DJ, Traylor-Knowles N, Bay RA. 2014. Mechanisms of reef coral resistance to future climate change. Science 344(6186):895-898.

DOI: $10.1126 /$ science. 1251336.

Pandolfi JM, Connolly SR, Marshall DJ, Cohen AL. 2011. Projecting coral reef futures under global warming and ocean acidification. Science 333(6041):418-422. DOI: $10.1126 /$ science. 1204794

Pinheiro J, Bates D, DebRoy S, Sarkar D, R Core Team. 2016. nlme: Linear and nonlinear mixed effects models. R package v 3.1-125. Available at: http:// CRAN.R-project.org/package $=$ nlme

Precht WF, Aronson RB. 2004. Climate flickers and range shifts of reef corals. Frontiers in Ecology and the Environment 2(6):307-314. DOI: 10.1890/1540-9295 (2004)002[0307:CFARSO]2.0.CO;2

Reynolds RW, Peterson TC, Lawrimore J. 2008. Improvements to NOAA's historical merged land-ocean surface temperature analysis (1880-2006). Journal of Climate 21:2283-2296. DOI: 10.1175/2007JCLI2100.1

R Core Team. 2016. R: A language and environment for statistical computing. R. Foundation for Statistical Computing. Available at: https://www.R-project.org/ Vienna-Austria

Rivera-Guzmán NE, Moreno-Casasola P, Ibarra-Obando SE, Sosa VJ, Herrera-Silveira J. 2014. Long term state of coastal lagoons in Veracruz, Mexico: Effects of land use changes in watersheds on seagrasses habitats. Ocean and Coastal Management 87:30-39.

DOI: 10.1016/j.ocecoaman.2013.10.007

Ruane AC. 2010. NARR's atmospheric water cycle components. Part I: 20-year mean and annual interactions. Journal of Hydrometeorology 11(6):1205-1219.

DOI: 10.1175/2010JHM1193.1

Ruiz-Moreno D, Willis BL, Page AC, Weil E, Cróquer A. 2012. Global coral disease prevalence associated with sea temperature anomalies and local factors. Diseases of Aquatic Organisms 100:249-261.

DOI: $10.3354 /$ dao02488

Saravanan R, Chang P. 2000. Interaction between tropical Atlantic variability and El Niño-Southern Oscillation. Journal of Climate 13(13):2177-2194.

DOI: 10.1175/1520-0442(2000)013<2177:IBTAVA $>2.0 . \mathrm{CO} ; 2$

Salas-Pérez JJ, Vargas-Hernández JM, Arenas-Fuentes V, Balderas-Cruz P. 2007. Trayectoria de masas de agua en los sistemas arrecifales de Veracruz y modelos numéricos: circulación de verano. In: Investigaciones 
cientificas en el Sistema Arrecifal Veracruzano (Granados-Barba A, Abarca-Arenas L, Vargas-Hernández JM, Eds.). EPOMEX-UAC, Mexico, 17-26.

Salas-Pérez JJ, Granados-Barba A. 2008. Oceanographic characterization of the Veracruz Reef System. Atmósfera 21(3):281-301.

Salas-Pérez JJ, Arenas-Fuentes V. 2011. Winter water mass of the Veracruz reef system. Atmósfera 24(2):221-231.

Salas-Pérez JJ, Salas-Monreal D, Monreal-Gómez MA, Riveron-Enzastiga ML, Llasat C. 2012. Seasonal absolute acoustic intensity, atmospheric forcing and currents in a tropical coral reef System. Estuarine Coastal and Shelf Science 100:102-112.

DOI: $10.1016 /$ j.ecss.2012.01.002

Salas-Pérez JJ, González-Gándara C. 2016. Temporal and spatial fluctuations of sea surface temperature and chlorophyll $a$ levels due to atmospheric forcing in a tropical coastal lagoon. Ciencias Marinas 42(1):49-65. DOI: $10.7773 / \mathrm{cm} . v 42 \mathrm{i} 1.2551$

Salas-Pérez JJ, Jordán-Garza AG. 2018. Oceanography of the reef corridor of the southwestern Gulf of Mexico. Nova Science Publisher, USA, $151 \mathrm{pp}$.

Sheridan CS. 2003. North American weather-type frequency and teleconnection indices. International Journal of Climatology 23(1):27-25. DOI: 10.1002/joc.863

Stahle DW, Cleaveland MK. 1992. Reconstruction and analysis of spring rainfall over the southeastern U.S. for the past 1000 years. Bulletin of American Meteorological Society 73:1947-1961.

DOI: $10.1175 / 15200477(1992) 073<1947$ :RAAOS$\mathrm{R}>2.0 . \mathrm{CO} ; 2$

Tang Z, Brody SD, Quinn C, Chang L, Wei T. 2010. Moving from agenda to action: Evaluating local climate change action plans. Journal of Environmental Planning and Management 53(1):41-62.

DOI: $10.1080 / 09640560903399772$
Tank A, Zwiers F, Zhang X. 2009. Guidelines on analysis of extremes in a changing climate in support of informed decisions for adaptation. World Meteorological Organization, Geneva, Switzerland, 52 pp.

Tejeda-Martínez A, Welsh-Rodríguez C, eds. 2006. Inundaciones 2005 en el estado de Veracruz. Universidad Veracruzana, Xalapa, Mexico, 432 pp.

Tett SF, Jones GS, Stott PA, Hill DC, Mitchell JF, Allen MR, Roberts DL. 2002. Estimation of natural and anthropogenic contributions to twentieth century temperature change. Journal of Geophysical Research: Atmospheres 107(D16):1230-1245.

DOI: 10.1029/2000JD000028

Tolika K, Maheras P, Flocas HA, Imitriou AP. 2006. An evaluation of a general circulation model (GCM) and the NCEP-NCAR reanalysis data for winter precipitation in Greece. International Journal of Climatology 26:935-955. DOI: 10.1002/joc. 1290

Tunnell JW, Chávez E, Withers K, Earl S. 2007. Coral reefs of the southern Gulf of Mexico. Texas A\&M University Press, USA, 216 pp.

Walther GR, Post E, Convey P, Menzel A, Parmesan C. 2002. Ecological responses to recent climate change. Nature 416(6879):389-395. DOI: 10.1038/416389a

Wiles GC, D'Arrigo RD, Barclay D, Wilson RS, Jarvis SK. 2014. Surface air temperature variability reconstructed with tree rings for the Gulf of Alaska over the past 1200 years. The Holocene 24(2):198-208.

DOI: $10.1177 / 0959683613516815$

Zhu J, Liang X-Z. 2013. Impacts of the Bermuda High on regional climate and ozone over the United States. Journal of Climate 26:1018-1032. DOI: 10.1175/JCLI-D-12-00168.1 